\title{
EL ABASTECIMIENTO Y LAS CRISIS DE LA SAL EN LOS PUERTOS DE A CORUÑA Y BETANZOS DURANTE LA SEGUNDA MITAD DEL SIGLO XVI
}

\author{
Por \\ FELIPE VALDÉS HANSEN
}

\begin{abstract}
RESUMEN
Se realiza un estudio sobre el abastecimiento de la sal en los puertos de Coruña y Betanzos durante la segunda mitad del siglo XVI, prestando especial interés a los periodos de carestía (1574-75/1598-99) y sus consecuencias. Igualmente se analiza todo lo relacionado con la gestión de los alfolíes en cada una de dichas ciudades a través de diversa documentación notarial y de los libros de cuentas de dichos alfolíes, a partir de los cuales también ha sido posible establecer las rutas marítimas del comercio de la sal entre ambos puertos y los de Portugal y Andalucía.
\end{abstract}

\section{PALABRAS CLAVE}

Sal, Abastecimiento y crisis, Coruña y Betanzos, Historia, Siglo XVI (segunda mitad). 


\begin{abstract}
A research is undertaken about the salt supply to the harbours of Corunna and Betanzos (NW of Spain) during the second half of the sixteenth century, in which the periods of scarcity (1574-75/1598-99) and their results are particularly stressed. A thorough analysis of everything connected with the management of the salt warehouses in both cities, through the documentation of the public notaries as well as the accountancy books of these warehouses, is equally included. From these records it has also been possible to establish the maritime salt trading routes between these two harbours and those of Portugal and Andalusia (South of Spain).
\end{abstract}

\title{
KEYWORDS
}

Salt, Supply and crisis, Corunna and Betanzos, History, Sixteenth Century (second half).

\section{INTRODUCCIÓN}

La importancia de la sal en el pasado, como producto indispensable para la conservación de la carne y del pescado en particular, es algo bien conocido sobre lo que no vamos a incidir en el presente artículo. Pero en Galicia fue aún mayor teniendo en cuenta que apenas existía una producción interna que cubriese la fuerte demanda de la actividad pesquera, surgiendo dos flujos comerciales contrarios e interdependientes: las exportaciones de pescado y las importaciones de sal. Tradicionalmente, se ha argumentado que la dependencia salinera de Galicia se agravó al convertirse la sal en un monopolio real mediante el Ordenamiento de Alfonso XI, en el año 1338, que dificultaba su libre abastecimiento implantando el sistema de alfolíes y por ello en los puertos gallegos se convirtió en un producto de importación vital ${ }^{1}$. En este contexto es comprensible el sur-

\footnotetext{
${ }^{1}$ FERREIRA PRIEGUE, E: Galicia en el comercio marítimo medieval, Fundación Barrié de la Maza, La Coruña, 1988, p. 162.
}

«CUADERNOS DE ESTUDIOS GALLEGOS», Tomo L, Fascículo 116, Santiago 2003. 
gimiento de ciertos conflictos como los intentos de impedir o encarecer su compra a los foráneos que acudían a las pesquerías gallegas, siendo necesaria la intervención del rey Enrique II en las Cortes de Toro de 1371 confirmando a los vascos y cántabros el derecho de comprar sal con la que poder salar el pescado y la carne de las ballenas en la costa gallega ${ }^{2}$.

Los de Coruña y Betanzos (que tratamos conjuntamente dada su proximidad y vinculación) son dos de los veinte alfolíes que mediado el siglo XVI había en Galicia junto a los de Ribadeo, Viveiro, Ferrol, Pontedeume, Corcubión, Muros, Noia, Pobra do Deán, Padrón, Vilagarcía, Cambados, Pontevedra (dos), Redondela, Vigo, Baiona, A Guarda y Tui³. En el apéndice documental incluímos la transcripción de los libros de cuentas de ambos alfolíes correspondientes a los años de 1565 (Coruña) y 1570 (Betanzos) en los que se registraban las entradas y salidas de sal, además de los cargos y descargos de dinero de manera pormenorizada ${ }^{4}$. Los receptores (administradores de los alfolíes) debían presentar dichas cuentas ante el administrador general de la sal del reino de Galicia. Así lo hicieron, respectivamente en los meses de enero de 1566 y 1571, Antonio González de Candame, del alfolí corunés, ante Cristóbal de Barros ${ }^{5}$ y

\footnotetext{
${ }^{2}$ «...que los de las villas de la marisma de Castiella e de Guypuzca e del Condado de Vizcaya que husaron e acostunbraron que algunos dellos llegavan en las villas de las marismas de Gallizia e de Asturias o en algunas dellas, que pagando los nuestros derechos reales que conpran sal e pescados frescos menudos e granados e vallenas e cavalletes e que los salganvan por si, e esto que se usara sienpre fasta agora de poco tienpo aca, et que agora los de las dichas villas de Gallizia e de Asturias o algunas dellas que fezieran nuevamente posturas e confradías e que gelo non querían consentir e que les enbargavan el dicho uso e costunbre que dizen que sienpre ovieron e acostunbraron...» Cortes de los antiguos reinos de León y Castilla, Real Academia de la Historia, vol. II, 1883-1903, pp. 213-214.

${ }^{3}$ CASTIÑEIRA CASTRO, V. M: «El litoral gallego y el abastecimiento de sal a mediados del s. XVI», Obradoiro de Historia Moderna, $\mathrm{n}^{\circ}$ 8, Santiago de Compostela, 1999, p. 24.

${ }^{4}$ Archivo Municipal de Coruña (en adelante A.M.C.), Protocolos notariales, s. XVI, caja $\mathrm{n}^{\circ} 2$ y Protocolos notariales, caja ${ }^{\circ}$ 1, Juan López de Taibo, años 1570-1571.

${ }^{5}$ Años más tarde encontramos en la década del 1570 a Cristóbal de Barros como secretario del rey encargado de cuestiones relacionadas con la organización de la Armada (construcción de barcos, censos de navíos disponibles en el País Vasco, conservación de los bosques, etc.). Quizás fue este cargo de administrador de la sal en Galicia uno de los primeros pasos que le permitió llegar a este otro de tanta relevancia en tiempos del reinado de Felipe II.
}

«CUADERNOS DE ESTUDIOS GALLEGOS», Tomo L, Fascículo 116, Santiago 2003. 
Andrés de Nebreda como receptor de Betanzos ante Pedro Ramos, administrador de los alfolíes de Galicia por aquel entonces ${ }^{6}$. La información que aportan ambos libros de cuentas nos permite conocer aspectos propios de la administración de los alfolíes, además de otros asuntos poco o nada conocidos respecto al suministro de la sal en esta parte de la costa gallega durante el siglo XVI tales como las rutas, los barcos y los maestres de la sal. Toda esta información se completa con los aportes documentales de los libros de actas del consistorio coruñés y otros documentos que nos han permitido conocer algo más de la crisis de la sal de 1574-75 y la existencia de otra, en 1598-99, coincidiendo con una epidemia de peste especialmente mortífera en Betanzos. Se incluye además referencias a los primeros años del s. XVII en el caso coruñés, al guardar relación con lo expuesto para el periodo que aquí nos ocupa.

\section{ENTRADAS DE SAL EN EL ALFOLÍ DE A CORUÑA}

Los registros del libro de cuentas permiten confirmar no sólo la irrupción en Galicia de la sal andaluza durante el siglo XVI, sino comprobar también que dichas importaciones se convirtieron en el principal suministro del alfolí coruñés. La mayor parte de la sal procedía de las salinas andaluzas de Sanlúcar de Barrameda (3.018 fanegas y otras 106 de resalga), del Puerto de Santa María (2.220 fanegas) y de las portuguesas de Aveiro (2.595 fanegas) ${ }^{7}$. Las remesas que llegaban desde estos puertos estaban muy por encima de las procedentes de otros lugares como Lisboa (234

\footnotetext{
${ }^{6}$ Por lo que respecta a los receptores sabemos de Antonio González de Candame que, además de ser un importante mercader, era el mayordomo que cobraba las rentas de la ciudad y que debió ser un personaje que alcanzó bastante notoriedad, ya que aparece en otros documentos de compraventa o litigios de carácter comercial. Mientras que Andrés de Nebreda años después fue también receptor del alfolí de Coruña. Por este orden después de Candame fueron receptores del alfolí coruñés durante estos años hasta principios del siglo XVII Gonzalo Hizquinio, Cristobal Román, Pedro de Lago, el ya mencionado Andrés de Nebreda, Juan López de Taibo, Bastián Pérez, Lope Álvarez de Baamonde y Rodrigo Álvarez de Baamonde. Archivo del Reino de Galicia (en adelante A.R.G.), Fondo Real Audiencia, leg. 8.276, $\mathrm{n}^{\circ} 12$.

${ }^{7}$ Dichas cantidades han sido calculadas a partir de la medida de sal utilizada en el alfolí que equivalía a tres fanegas de Ávila.
}

«CUADERNOS DE ESTUDIOS GALLEGOS», Tomo L, Fascículo 116, Santiago 2003. 
fanegas y otras 63 de resalga) y el País Vasco (poco más de 21 fanegas), sal que en este último caso muy probablemente procedería de las salinas francesas ${ }^{8}$. Aquel año no arribó ninguna nao francesa con un cargamento de sal pero dichas importaciones no eran raras, aunque se trataba de una sal de peor calidad dado que su precio de venta era inferior al de la sal andaluza y portuguesa ${ }^{9}$. Sin embargo, en el año 1604 sí hay noticia de una urca francesa denominada «La Esperanza» del maestre Nicolás Dupis que dejó la ingente cantidad de 2.465 fanegas de sal.

Las salinas andaluzas de la costa atlántica (relativamente poco importantes durante la Edad Media por encontrarse a medio camino entre las salinas portuguesas y las del Mediterráneo) se convirtieron a partir del XVI en los centros productores que abastecieron el puerto coruñés en detrimento incluso de los portugueses como Aveiro, cuya mayor proximidad respecto a Galicia no fue un obstáculo para la competencia andaluza. No es de extrañar, teniendo en cuenta que las importaciones andaluzas se veían favorecidas por las buenas relaciones entre los alfolineros gallegos y los salineros andaluces, los cuales incluso otorgaban su poder a los primeros para que tratasen todo lo concerniente al negocio de la sal en los puertos gallegos ${ }^{10}$. Sin embargo, paradojicamente el transporte de la sal andaluza estaba en manos de los «maestres de la sal» portugueses de importantes centros salineros como Leza o Tavira (buenos conocedores del oficio y transportistas especializados), siendo casi nula la presencia de los gallegos en dicho negocio. Tan sólo tenemos noticia de la actividad de un vecino coruñés, Pedro de Abilles, que aprovechaba los tornaviajes a Lisboa para traer pequeñas partidas de sal, argumentándose para la Baja Edad Media que esta circunstancia vendría motivada por la falta de bar-

${ }^{8}$ Para la Baja Edad Media ya se ha señalado la posibilidad que la sal francesa llegase a Galicia a través de transportistas vascos. ARMAS CASTRO, J: Pontevedra en los siglos XII a XV, Fundación Pedro Barrié de la Maza, La Coruña, 1992, p. 191.

${ }^{9}$ A.M.C., Acuerdos del consistorio, caja 7, libro 11, fols. 173 r, 252 v-253 r, 273 v. Y Caja 8, libro 12, fol. 35 r. Podría tratarse de sal gema según VELO PENSADO, I: La vida municipal de A Coruña en el siglo XVI, Diputación de A Coruña, 1992, p. 117.

${ }^{10}$ De este modo sabemos por ejemplo que el receptor del alfolí Antonio González de Candame en 1567 era el apoderado de Juan Binagre, vecino del Puerto de Santa María, en Galicia para todo lo concerniente a su negocio de la sal (contratas, cobro del dinero, etc.). A. M. C., Protocolos notariales s. XVI, caja ${ }^{\circ} 3$, fol. 150-151.

«CUADERNOS DE ESTUDIOS GALLEGOS», Tomo L, Fascículo 116, Santiago 2003. 
cos ocupados la mayor parte del año en el transporte de grandes cantidades de pescado ${ }^{11}$.

En cuanto a las embarcaciones en las que se realizaba el transporte de la sal sabemos que con anterioridad al siglo XVI eran mayoritariamente utilizados los pequeños bajeles cuya tripulación era bastante numerosa. El privilegio del que gozaban los marineros naturales del puerto que les permitía sacar cierta cantidad de sal libre de derechos y el nada costoso flete de estas embarcaciones hizo que se convirtiesen en los barcos preferidos para su transporte, pudiendo incluso de esta manera descargarse grandes cantidades de sal sin que el alfolí cobrase por ello derecho alguno ${ }^{12}$. Pero entre los barcos que descargaron en este puerto no faltan los de gran porte como las naos a excepción de una pinaza vasca y el barco gallego que, a tenor de las cantidades de sal, no debiera ser muy grande (si es que esta remesa no iba acompañada de otras mercancías procedentes de Portugal).

Del libro de cuentas se desprende que las descargas de sal se realizaban a lo largo del año sin que se concentrasen claramente en un mes determinado, aunque cabe destacar que más de la mitad se corresponden con el último período del año, a partir del 31 de agosto, coincidiendo con la mayor actividad salazonera y pesquera desde el mes de septiembre. Es también apreciable en dichos meses un ligero descenso del precio de la medida de sal, cuando era más abundante tras ser cosechada durante los meses calurosos del verano, aumentando su valor una vez que empezaba a escasear en el mercado.

\section{INGRESOS Y GASTOS DE DINERO DEL ALFOLÍ DE A CORUÑ A}

El dinero con el que contaba el alfolí procedía de las arcas de la hacienda real y por medio del administrador de la sal y alfolíes de Galicia se confiaba a los receptores que debían dar cumplida cuenta a principios de cada año de los gastos (descargos) e ingresos (cargos). Con dicho dinero,

\footnotetext{
${ }^{11}$ FERREIRA PRIEGUE, E: Galicia en el comercio..., p. 167.

${ }^{12}$ Ibid., p. 166.
} 
además de proveerse de sal, se debía costear también los sueldos de los trabajadores, el alquiler y mantenimiento de las lonjas donde se guardaba la sal, la adquisición, reparo y transporte de los instrumentos que fuesen necesarios (medidas, etc.) y otros gastos eventuales. Aún así el margen de beneficio del receptor era bastante alto teniendo en cuenta que el precio de la «sal blanca» que compraba a los tratantes oscilaba entre los cuatro y cinco reales la medida, mientras que la llegaba a vender por quince reales. $\mathrm{Al}$ igual que en el caso de la "sal de resalga» donde el beneficio era también considerable, ya que se adquiría a dos reales y su precio de venta alcanzaba los nueve reales aún tratándose de una sal que ya se había usado en la salazón. Ésta se distinguía claramente por su color marrón y ello se debía a la grasa del pescado que había absorbido durante dicho proceso, sobre todo en aquellos meses en los que el pescado como la sardina tiene una mayor cantidad de grasa durante el verano, por lo que su calidad era ínfima y hasta hace poco tiempo se regalaba como abono para los campos de cultivo sin darle otra mayor utilidad ${ }^{13}$. Aunque su comercio durante el siglo XVI puede indicarnos otros usos similares a los de la «sal blanca» y venderse como sal de baja calidad entre los estratos más pobres de la sociedad o durante los períodos de carestía.

Para el alfolí trabajaban dos medidores, un escribano (que percibía el sueldo más elevado por registrar las entradas y salidas de sal o dinero) y los porteadores, aunque en ocasiones no era necesario recurrir a ellos si la venta se producía al pie del barco sin que la sal llegase al alfolí o a las lonjas. Una cantidad menor del dinero se destinaba a los trabajadores indirectos que se beneficiaban del funcionamiento del alfolí, como los herreros y toneleros que elaboraban los utensilios de medición, los hombres y mujeres (las «mandaderas» de antaño) encargados de su transporte desde el lugar donde se realizaban dichos instrumentos o aquellos otros que lo abastecían de sacos, etc.

\footnotetext{
${ }^{13}$ Comunicación personal de Arturo Romaní García, descendiente de una familia catalana dedicada en el pasado a la industria de la salazón en la ría de Muros y autor de varios libros relacionados con la actividad pesquera y la industria salazonera en Galicia entre los que cabe citar ROMANÍ GARCÍA, A: A revolución tecnolóxica na industria salgadeira de Galicia, Vigo, 1991. ROMANI GARCÍA, A: Una industria salazonera catalana en Galicia, origen, apogeo y ocaso: la familia Romaní, Xunta de Galicia, Santiago de Compostela, 1998.
}

«CUADERNOS DE ESTUDIOS GALLEGOS», Tomo L, Fascículo 116, Santiago 2003. 
Además de los gastos propios del alfolí el receptor debía hacer frente al pago de una serie de rentas como la que disfrutaban los «pobres lacerados», que regentaban el desaparecido lazareto o leprosería que se hallaba a extramuros de la ciudad en el arrabal de Santa Lucía, los cuales percibían el valor correspondiente a ocho fanegas de sal de cada descarga (en total 2.554 maravedís en 1565). La primera noticia documentada es del año $15633^{14}$ pero dicho privilegio se remontaba a una merced real dada en tiempos de los reyes católicos, la cual se perdió junto a otros documentos por culpa del incendio que asoló dicho hospital durante el ataque de los ingleses en $1589^{15}$. Para recibir dicha sal o su correspondiente valor en dinero los «pobres de San Lázaro» acudían abordo de cada nao o carabela en alguna de las barcas disponibles en la ribera del puerto ${ }^{16}$. Si bien a lo largo de la segunda mitad del siglo XVI no hubo resistencias a su pago, ello cambió a principios del siglo XVII siendo Antonio Pereira administrador de la sal en Galicia y desde el año 1603 fueron frecuentes los impagos y las consiguientes protestas del mayordomo de la orden.

Nada se nos dice en el libro de cuentas sobre otras rentas como los cuarenta moyos de sal que correspondían al monasterio de Sobrado, desde que así lo estableciera María de Molina en el año 1300, convertidos

${ }^{14}$ El 21 de mayo de 1563 el mayordomo de la orden de San Lázaro, Vasco Doldao (o de Oldao), arrendó este beneficio durante diez años por nueve ducados anuales a Jácome de Sosa, vecino de Coruña. Archivo Histórico de Protocolos del Colegio Notarial de La Coruña (en adelante A.H.P.), Protocolos Notariales de Coruña, $\mathrm{n}^{\circ} 1$, fol. 90r-91r.

${ }^{15}$ «...que si los dichos pobres tenian merçed de pribilexio de su magestad o de los señores reys católicos el testigo no los a bisto, mas que si los tenían se les an quemado porque el enemigo inglés quando llebantó el çerco desta çiudad de La Coruña quemó la yglesia de Santa Luçía y a todas las casas de los pobres y enfermos de San Lázaro con toda la pobreça que en ellas tenian y hestubieron cautibos todo el tiempo que turó el dicho çerco y después por seren tales enfermos y no de probecho les dexaron por donde sabe el testigo que tenían algunos papeles se los quemaron...» A.R.G., Fondo Real Audiencia, leg. 8.276, $\mathrm{n}^{\circ} 12$. Sobre la concesión de esta merced por parte de los reyes católicos no hay duda alguna según el testimonio del procurador de los de San Lázaro en el año 1604: «...sobre la limosna y merced de los reyes católicos de gloriosa memoria les havian hecho en cada navio de sal que se descargasse en esta ciudad...», Ibid.

${ }^{16}$ «...la qual dicha sal se les pagaba a bordo de cada nabio y el mayordomo de los dichos enfermos lo yba a cobrar en una barca, la primera que allaba en la ribera de qualquiera vecino desta...», testimonio del mareante coruñés Pedro Manríquez «el viejo». A.R.G., Fondo Real Audiencia, leg. 8.276, n 12.

«CUADERNOS DE ESTUDIOS GALLEGOS», Tomo L, Fascículo 116, Santiago 2003. 
desde 1571 en 40.000 maravedís ${ }^{17}$, de cuyo cobro sólo tenemos noticia en los años de $1584^{18}$ y en $1585^{19}$ a través del prior del monasterio de las Cascas de Betanzos (que pertenecía al de Sobrado desde el siglo XII ${ }^{20}$ ). Una cantidad similar, 31.000 maravedís, percibía anualmente la cofradía de mareantes de San Andrés a cuyos mayordomos y vicarios pagaba el receptor del alfolí en una o dos pagas ${ }^{21}$.

Por último, comentar que gracias a los descargos o gastos de dinero podemos saber que eran dos o tres los depósitos donde se guardaba la sal además del alfolí. En primer lugar estaba la «lonja grande», cuyo alquiler pagaban al mayordomo del cabildo de la colegiata de Santa María del Campo y del que se descontaban los gastos derivados de reacondicionar el local para asegurar una buena conservación del producto. Más pequeña debía ser la «lonja de peligro» donde se almacenaría la sal indispensable durante los períodos de carestía cuando se cortaba el normal suministro a causa de un conflicto bélico o baja producción de las salinas. También podía recurrirse al bajo de alguna casa de la vecindad pagando el corres-

${ }^{17}$ TETTAMANCY GASTÓN, Francisco: Apuntes para la historia comercial de La Coruña, 1900, p. 31.

${ }^{18}$ «...paresçió presente el muy reverendo padre frai Bernaldo Díaz, çillero y procurador del monasterio de Santa María de Sobrado de la horden de San Vernaldo y por vertud del poder que tiene del abad, monjes y convento del dicho monasterio...conoció y confesó aver rescivido del señor Martín Aragonés, administrador general por su majestad de los alfolís de la sal desta çiudad quarenta mill maravedis de un año entero que feneçió a veynte y tres de junio deste dicho año por otros tantos quel dicho monasterio tiene de juro en cada año...», A.H.P., Protocolos Notariales de Coruña, ${ }^{\circ} 35$, fol. 103r.

${ }^{19}$ El 4 de enero de 1585 frai Martín Vitoria, prior del monasterio de Nuestra Señora de las Cascas, en nombre del abad del monasterio de Sobrado recibió 20.000 maravedís (renta de medio año) de mano del receptor del alfolí de Coruña Andrés de Nebreda. A.H.P., Protocolos Notariales de Coruña, $n^{\circ} 30$, fol. 5r-v. Es de suponer que no figura esta renta en el libro de cuentas de 1565 por haberse realizado el pago directamente a través del administrador de la sal de Galicia (así fue en el año 1584) y no del receptor del alfolí como en el año 1585.

${ }^{20}$ La donación de la propietaria de dicho monasterio doña Urraca Bermúdez, hija de Bermudo Pérez de Traba, se realizó el 8 de septiembre de 1145. FREIRE CAMANIEL, J: El monacato gallego en la Alta Edad Media, Fundación Pedro Barrié de la Maza, A Coruña, 1998, pp. 730-731.

${ }^{21}$ Los vicarios y mayordomos de dicha cofradía dieron cartas de pago a favor de Martín Aragonés, administrador de los alfolíes de Galicia, por $15.250 \mathrm{mrs} ., 15.500 \mathrm{mrs}$ y 30.500 maravedís que les entregó el receptor Andrés de Nebreda en 1584, 1585 y 1586. A.H.P., Protocolos Notariales de Coruña, $n^{\circ} 29$, fol. 66r; $n^{\circ} 30$, fol. 19r-20r; $n^{\circ} 31$, fol. $94 r$.

«CUADERNOS DE ESTUDIOS GALLEGOS», Tomo L, Fascículo 116, Santiago 2003. 
pondiente alquiler por ello. Vemos pues que la existencia de un alfolí no implicaba la centralización de todo lo concerniente a la sal o al menos de su depósito.

\section{EL PROBLEMA DEL ABASTECIMIENTO}

El derecho de almacenamiento y distribución de la sal fue concedido por Alfonso X a la ciudad de Coruña el 2 de diciembre de 1255 en detrimento de la ciudad de Betanzos. Dicho privilegio fue confirmado posteriormente por Sancho IV en el año $1286 \mathrm{y}$, contrariamente a lo que se podría pensar, ello no garantizaba el abastecimiento del alfolí coruñés, fundamentalmente por culpa de los intereses de los receptores que se convirtieron en un lastre para el desarrollo de la actividad pesquera. Las nefastas consecuencias que se podían derivar de un deficiente abastecimiento de los alfolíes se trataban de evitar estableciendo duras penas al receptor que no cumpliese con sus obligaciones y suministrase toda la sal que los pescadores de la ciudad demandasen ${ }^{22}$. Ante esta situación, no es de extrañar que fuese una costumbre su comercio al margen del alfolí y en los momentos en que se intentaba atajar esta costumbre se producían las consiguientes quejas de los vecinos ${ }^{23}$, hasta que en 1564 el nuevo monopolio establecido por Felipe II impuso la obligatoriedad de comprar sal solamente en los alfolíes.

Mediado el siglo XVI todavía no existían grandes dificultades por lo que respecta a su abastecimiento. Prueba de ello, es que incluso en el año

${ }^{22}$ El 30 de agosto de 1569 el administrador de los alfolíes y de la sal del reino de Galicia Lope de Ramos instaba a Antonio González de Candame, receptor del alfolí de Coruña, a que «...tenga quenta de la bender e beneficiar, venda e beneficie segund e como es obligado y le está mandado dándola abasto de ordinario a todas las personas que la fueren a conprar, sin que por defecto de no darla venderla e beneficiarla como es obligado los pescadores y otras personas que la ubieren de conprar resçivan daño ni agravio ni se les pierdan sus pequerías ni açienda, lo qual cumpla sopena de dos mill ducados para la camara de su magestad...», A.M.C., Protocolos notariales s. XVI, caja 3, fol. $134 \mathrm{r}$.

${ }^{23}$ En 1489 pidieron que se ordenase a los arrendadores del alfolí que les «...dejen alfolinar e traher a descargar en la dicha çibdad e salar sus pescados e se aprovechar dellas segund syempre lo fisieron...», FERREIRA PRIEGUE, E: Galicia en el comercio..., p. 172, n. 259.

«CUADERNOS DE ESTUDIOS GALLEGOS», Tomo L, Fascículo 116, Santiago 2003. 
1557 en el puerto coruñés había una flotilla de dos carabelas portuguesas con sal, de las cuales se permitió la partida a una de ellas para que vendiese la sal que transportaba en el puerto que considerase oportuno (posiblemente Betanzos) por ser suficiente con la mercancía de la carabela de mayor porte ${ }^{24}$. Hasta 1564 el precio del ferrado de la sal que se vendía al margen del alfolí (y que controlaba el concejo corunés) es también revelador en este sentido, ya que con anterioridad a los períodos de carestía tendió a la baja $\mathrm{a}^{25}$.

Pero en el año 1574 y 1575 no sólo la ciudad coruñesa, al igual que la de Betanzos, se vio afectada por la crisis de abastecimiento que afectó a toda la costa gallega, sino que además hubo un conflicto entre la justicia municipal y la Real Audiencia, dado el empecinamiento del receptor de seguir vendiendo sal a los mercaderes foráneos en detrimento de los vecinos a pesar de la carestía y de las consiguientes quejas del consistorio municipal. Desde el concejo, en el mes de agosto de 1574, se trató de atajar estas «fugas de sal» poniendo cortapisas a dichas ventas y obligando a vender sal a los que recalaban en el puerto de la ciudad ${ }^{26}$. Aunque con anterioridad, en el mes de abril, una provisión real había sido expedida aconsejando al consistorio coruñés sobre la necesidad de dar prioridad a los barcos cargados de sal, reduciendo de esta manera en lo posible a los

\footnotetext{
${ }^{24}$ «Luego en este regimiento los dichos señores mandaron que los portugueses que tienen las dos carabelas de sal en el puerto desta cibdad, dejenla una dellas que sea la mayor e la hotra la llieben a donde quisieren...», A.M.C., Acuerdos del consistorio, caja 7, libro 11, fol. $88 \mathrm{r}$.

${ }^{25} \mathrm{Si}$ en 1558 la sal de Andalucía costaba 30 maravedís y la francesa 25 mrs., en 1559 la andaluza sólo costaba medio real el ferrado y $14 \mathrm{mrs}$. la francesa. Y aunque en los años sucesivos fue aumentando su precio en 1564 todavía era inferior al de 1558 ( $24 \mathrm{mrs}$. la andaluza y portuguesa y medio real la francesa). A.M.C., Acuerdos del consistorio, caja 7, libro 11, fols. 173 r, $273 \mathrm{v}, 252 \mathrm{v}-253 \mathrm{r}$, caja 8, libro 12, fol. $35 \mathrm{r}$.

${ }^{26}$ «...Luego los dichos señores dixeron que atento que Martín Caballero, maestre francés, abía comprado en el alfoli desta çibdad la cantidad de sal y el alfolí quedaba desprobeido, abía muchos daños e los vecinos padesçían, mandaron que el dicho Martín Cavallero de las dos partes de la sal quite a preçio de real e medio cada una y la una parte quede para él y ansy mandaron que lo susodicho fuese noteficado y para ello se conpela un bedor o el alguazil de la çibdad y ello se haga conforme al repartimiento que se le dará. Y a Juan Guerra se le notefique de las quatro pipas de sal que traxo, de una dellas a la çibdad para que se reparta entre los vecinos y se le pague a razón de real e medio cada ferrado...», (21 agosto 1574), A.M.C., Acuerdos del consistorio, caja 9, libro 14, fol. $124 \mathrm{r}$.
}

«CUADERNOS DE ESTUDIOS GALLEGOS», Tomo L, Fascículo 116, Santiago 2003. 
transportistas salineros los costos propios de la arribada y estiba, tratando así de incentivar su entrada en los puertos donde había escasez de dicho producto $^{27}$. Pero, a pesar de todo, la carestía continuó y en 1575 la crisis alcanzó su momento más crítico con el enfrentamiento entre la justicia local y la Real Audiencia, tras el apresamiento y encarcelamiento del receptor por las razones anteriormente aludidas ${ }^{28}$.

A lo largo de aquellos años fueron frecuentes las quejas por los abusos de los receptores, la carestía y el elevado precio de la sal. La visita realizada por un enviado del rey para conocer la situación de los alfolíes gallegos en 1566 evidenció que, ya desde entonces, Galicia estaba mal abastecida por culpa de los receptores. Éstos entre otras artimañas mezclaban la sal de «resalga» con la «blanca» y la vendían al precio de esta última o se aprovechaban del sistema de medición desde que el receptor de Betanzos empezó a comprarla «pisada» y venderla «suelta» (ocupando un mayor volumen la misma cantidad de sal), obteniendo con ello una considerable ganancia a su favor con cada medida ${ }^{29}$. Durante este periodo fue especialmente grave el desinterés de los tesoreros de la sal por proveer a Galicia de este producto, ya que les resultaba más provechoso esperar la llegada de los barcos de fuera que hacerla traer desde los puertos salineros por su propia cuenta y riesgo. Por todo ello, no es de extrañar los intentos del concejo coruñés de hacerse con el control del alfolí en $1576^{30}$, incluso

${ }^{27}$ «...este reino estaría mas probeido de sal y en los nabios que la trajesen a el fuesen preferidos a todos los demás en las cargas y fletes de todo genero de mercadurías que recargasen en este reino...», A. M. C., Acuerdos del consistorio, caja 9, libro 14, fol $54 \mathrm{v}-55 \mathrm{r}$.

${ }^{28}$ «...En este regimiento se trató como el señor oydor [...] benía a esta çiudad con çédula de su majestad a proceder contra este ayuntamiento y contra el licenciado Balcazar, theniente que fue desta çiudad, sobre dezir avian preso a Pedro de Lago, reçetor del alfoli de la sal y otros sus criados y procedido contra ellos y meterse en lo tocante a la sal y porque este ayuntamiento y el dicho licenciado Balcazar, theniente que al presente era, bisto el gran deshorden que el dicho Pedro de Lago thenía en la benta del dicho sal y sus ofiçiales y personas que en ello asistian y que no lo quería dar a los vecinos desta çiudad, antes lo daban a forasteros y rescivian muchos coechos y sin [...] de lo que su magestad mandaba, haziendo en todo hello grandes esçesos y de tal manera que todo el pueblo padesçía y estaba perdido y revuelto...», (25 febrero 1575), A.M.C., Acuerdos del consistorio, caja 9 , libro 14 , fol. 188 r.

${ }^{29}$ CASTIÑEIRA CASTRO, V. M: «El litoral gallego...», pp. 21, 25.

${ }^{30}$ A. M. C., Acuerdos del consistorio, caja 9, libro 15, fol. 31 v- 32 r (2 mayo 1576).

«CUADERNOS DE ESTUDIOS GALLEGOS», Tomo L, Fascículo 116, Santiago 2003. 
actuando de forma conjunta con otras ciudades como Pontevedra en $1582^{31}$, y tampoco debe extrañarnos la aparición de otra crisis entre 1598 y 1599 en todo el reino de Galicia. Aprovechándose de dicha carestía los tratantes que recalaban en Coruña, Betanzos y otros puertos del litoral gallego la vendían a un precio muy elevado y abusivo, lo cual se podía solucionar mediante un abastecimiento directo al margen de estos intermediarios que se aprovechaban de la crisis. Pero el administrador de la sal no mostraba gran interés por abastecer los alfolíes por su propia cuenta, ya que cobraba a los tratantes de la sal un dinero por cada fanega desembarcada. De ello informó, en el año 1599, el procurador de la ciudad de Coruña, Luis do Campo, a la Real Audiencia de Galicia para que a su vez se diese noticia de ello al rey y se tomasen las medidas oportunas para restablecer el normal suministro y precio de la fanega ${ }^{32}$. Un año antes mediante una real provisión, dada en Madrid el 6 de mayo de 1598, ya se había instado al administrador de la sal a que restituyese dicho precio tal y como había sido concertado al tomar posesión de su cargo, al tiempo que se relacionaba dicha carestía con la aparición de hambrunas y epidemias ante la imposibilidad de conservar el pescado o la carne en muchos lugares de la comarca de Santiago, Coruña y especialmente en la ciudad de Betanzos, donde el hambre y la enfermedad se cebó mortalmente con la población:

«A vos Juan Pasqual, administrador de las salinas de Castilla, salud y gracia. Sepades que por parte del governador y alcaldes mayores de la nuestra audiencia del reino de Galicia, nos a sido fecha relación que a venido a faltar la sal en aquel reyno, teniendo bos e obligación de proverla con abundançia a quatro reales la anega. Y por descuido

\footnotetext{
${ }^{31}$ A. M. C., Acuerdos del consistorio, caja 10, llibro 16, fol. 138 r (2 agosto 1582).

32 «...la falta de sal hes muy grande y se padece muy gran necesidad, porque no ay sal con que poder salar las carnes y pescados y demás cossas que hes necesario, y si alguna ay hes muy poca y se bende a muy grandes y ecesibos precios, porque del tesorero general de la sal ni a esta ciudad ni a otro ningún lugar deste reyno de que se tenga noticia no se a traido ninguna sal dende el mes de junio que a hecho su asiento y se entiende no la traerá porque le será de mas provecho el no traerla, llevando de cada anega dos reales de los que la trujieren que traerla el por su cuenta. Todo lo qual resulta en gran daño y perjuycio de los naturales deste reyno y porque los que la traen la benden a ecesibos precios...», A.R.G., Fondo Real Audiencia, leg. 9.743, $\mathrm{n}^{\circ} 11$, fol. 2 r.
} 
o malicia de buestros ministros con gran dificultad se alla alguna y es a precio tan exsesivo que pasa en algunos lugares de sesenta reales la anega de lo qual y de otras desordenes a resultado grandísimo daño y averse descubierto enfermedades contagiosas y pestilentes de nacidas y carbuncos en muchos lugares en la comarca de la çiudad de Santiago y en la de La Coruña, de que an muerto muchas personas y particularmente avía sido y era mayor el daño en la ciudad de Vetanços, tres legoas de la dicha ciudad de La Coruña, suplicándonos hos mandasemos que conpeliendo el asiento que tenéis hecho sobre la provisión de la sal, proveyesedes de toda la neszesaria en aquel reino al precio concertado en ello. $\rangle^{33}$

Es evidente que por todo lo anteriormente referido el suministro de sal en Betanzos era igualmente muy precario, aunque también podía verse desabastecido por accidentes fortuitos como el acaecido en el año 1570 y del que hablaremos a continuación.

\section{ENTRADAS DE SAL EN EL ALFOLÍ DE BETANZOS}

En el caso de Betanzos, al contrario que en el libro de cuentas del alfolí coruñés, no hay registro alguno que nos informe sobre el origen de la sal y por tanto ninguna evidencia tenemos sobre su posible procedencia desde el Golfo de Cádiz, aunque como ya hemos visto el hecho de encontrarnos sólo a los tratantes portugueses no debe llevarnos a descartar que en un principio ello sí pudiera ser así. La cantidad desembarcada en 1570 (3.663 fanegas) es inferior a la registrada en el puerto coruñés en 1565 (9.699 fanegas y media, además de 381 fanegas de resalga). Ello es lógico teniendo en cuenta la menor importancia pesquera de este otro puerto y que además el de Coruña debía abastecer un tramo costero muy amplio y necesitado de sal (La Costa de la Muerte), desprovisto de alfolí alguno hasta el siglo XVII. Allí se localizaban puertos como Caión y Malpica, en los cuales se desarrollaba una importante actividad pesquera de amplio espectro que incluía a las ballenas y otros

\footnotetext{
${ }^{33}$ Ibid., fol. 35r-v.
}

«CUADERNOS DE ESTUDIOS GALLEGOS», Tomo L, Fascículo 116, Santiago 2003. 
grandes cetáceos ${ }^{34}$. Si bien ya tenemos noticia del alfolí de Laxe en el año 1615 , durante el tiempo que aquí nos ocupa el de Coruña era al norte el más próximo y el de Corcubión lo era al sur. En Betanzos sí había un mes determinado para abastecer el alfolí (noviembre), que coincidía con la bajada del precio de la sal recién cosechada y con la costera o temporada de pesca de la sardina que se prolongaba desde el mes de septiembre hasta finales de diciembre, dado que durante este tiempo la sardina se encontraba en las mejores condiciones tanto para ser consumida en fresco como para ser conservada ahumada ${ }^{35}$.

El alfolí de Betanzos alcanzó una gran importancia que se mantuvo a lo largo del siglo XVI, ya que abastecía los obispados de Mondoñedo y Lugo, y no menos importante era que los proveedores contasen con ciertas ventajas de tipo económico respecto a otros alfolíes ${ }^{36}$. Es por ello que, a pesar del «privilegio de la sal» de 1255 otorgado por Alfonso X y confirmado por Sancho IV en el año $1286^{37}$, a Betanzos seguían acudiendo barcos que vendían y descargaban la sal directamente allí haciendo caso

\footnotetext{
${ }^{34}$ Durante la segunda mitad del siglo XVI hemos podido comprobar como en el puerto de Malpica los mareantes acudían al alfolí coruñés para abastecerse de grandes remesas de sal en los días previos al inicio de una «armada de ballenas».

${ }^{35}$ «...por estar como está la dicha sardina en el dicho tiempo mas asazonada [...] ansi para que pueda mejor conserbarse y no podrirse y della se pueda aprovechar todo el reino como se aprovecha, como porque en aquel tiempo la dicha sardina está en su revor y seer con mas pescado e gordura que en otro tiempo del año...», Ordenanzas de la pesca de Pontevedra de 1557. ARMAS CASTRO, J: Pontevedra en ..., p. 142. La sardina con grasa no sirve para ahumar porque se derrite por completo con la acción del calor, mientras que durante este tiempo ya ha perdido la grasa siendo todavía gorda y no escuálida o espinosa como en los meses de enero a abril. ROMANÍ GARCÍA, A: La pesca de bajura en Galicia, Edicións do Castro, 1981, A Coruña, pp. 49-50.

${ }^{36}$ «.... y ay aqui el mejor alfoli de sal de todo el reyno con muchas preminencias sobre los otros alfolies...», MOLINA, «Licenciado»: Descripción del reino de Galicia, Colección Bibliófilos Gallegos, Santiago de Compostela, 1949, fol. XXIX v. FERREIRA PRIEGUE, E: Galicia en el comercio..., p. 115.

${ }^{37}$ Dicho privilegio concedía a la ciudad de Coruña el monopolio de la descarga y administración de la sal. A.M.C., Traslados de privilegios $\mathrm{n}^{\circ} 5 \mathrm{y} \mathrm{n}^{\circ} 12$, «Otrossí mando et defiendo que ninguna barca nin nauio grande nin pequenno sea osado de aportar en Betanzos con sal. Et quando los de Betanzos quisieren comprar sal dellos de La Crunna comprenlo et aduganlo a su villa por tierra dando todavía sus derechos en La Crunna et o los ovieren a dar, et los de La Crunna uenda la sal a los de Betanzos cuemo a los otros de la tierra, et non les fagan hy otra escatima.» GONZÁLEZ GARCÉS, M: Historia de..., p. 490.
}

«CUADERNOS DE ESTUDIOS GALLEGOS», Tomo L, Fascículo 116, Santiago 2003. 
omiso a la prohibición que les obligaba a hacerlo previamente en el puerto coruñés. Al no tener noticia de ninguna otra confirmación de dicho privilegio no parece que el mismo planteáse un gran obstáculo al alfolí de Betanzos, dado que era impensable que el de Coruña pudiese abastecer también a este otro cuando no era capaz en ocasiones ni de garantizar su propio aprovisionamiento. Aunque cabe la posibilidad que estas carabelas portuguesas llegasen a Betanzos previa parada, descarga y autorización en el puerto coruñés para arribar en otros puertos ${ }^{38}$. En 1570 desde Coruña únicamente llegó una partida de sal a Betanzos en dos volanteros y se trataba tan sólo de una parte del cargamento de una carabela que días antes había dejado en aquel otro puerto un total de 225 moyos. Posiblemente se trataba de un "envío de urgencia» para abastecer el alfolí de Betanzos, mermado en sus existencias de forma imprevista al perderse gran parte del cargamento de la carabela portuguesa «Santo Antonio,» que, tras soltarse las amarras por culpa de un "gran diluvio y mareas», encalló en el puente de la villa averiando el casco y anegando la bodega ${ }^{39}$.

No encontramos aquí los barcos de gran porte como las naos portuguesas que descargaban sal en el puerto coruñés y cuyo calado imposibilitaba cualquier intento de remontar la ría de Betanzos hasta el puente de la ciudad. Posiblemente eran ya evidentes los problemas de cegamiento de la ría tras los sucesivos depósitos aluviales de los ríos Mendo y Mandeo, que la convertían en un lodazal dificilmente navegable al igual que sucedía en el resto de las rías gallegas. Es por ello que aquí vemos las carabelas portuguesas, cuyo origen más reciente o desarrollo tardío se remonta precisamente a los problemas derivados del cegamiento de los estuarios portugueses del Douro, Lima y Miño durante el siglo $\mathrm{XV}^{40}$. Posiblemente

\footnotetext{
${ }^{38}$ Véase nota a pie de página $\mathrm{n}^{\circ} 24$

${ }^{39}$ «...Esta caravela llevava tres millares de sal y con gran dullubio (sic) e mareas estando amarrada en la dicha çiudad de Betanzos dio al través en la puente donde se anegó toda la sal, eçeto las dichas veynte e çinco medidas...", Apéndice documental II, fol. $77 \mathrm{r}$.

${ }^{40}$ FERREIRA PRIEGUE, E: Galicia en el comercio..., p. 258. Según la misma autora a fines del siglo XV apenas se aventuraban hasta Betanzos pequeñas embarcaciones bretonas que compraban vino y que constituían prácticamente su único movimiento portuario (ibíd, p. 114). Aunque hay que contar también con la arribada de estas carabelas de la sal todavía en la segunda mitad del siglo XVI y muy posiblemente bien avanzado el siglo XVII.
}

«CUADERNOS DE ESTUDIOS GALLEGOS», Tomo L, Fascículo 116, Santiago 2003. 
por ello con el paso del tiempo se aprecia una preferencia de los transportistas portugueses hacia este tipo de barco de pequeño porte, dado que a principios del siglo XVII eran carabelas todos los barcos que descargaron sal en el puerto de Coruña, mientras que en el año 1565 todavía hay constancia de al menos dos naos además de varios navíos sin especificar ${ }^{41}$. Estas carabelas, de un tamaño considerablemente menor, remontaban sin dificultad las rías que presentaban estos inconvenientes gracias a su versatilidad y a la resistencia del casco que permitía que las embarcaciones quedasen varadas una vez que bajaba la marea en los estuarios y las rías. $\mathrm{Al}$ igual que los volanteros que eran unas embarcaciones pesqueras muy utilizadas para el transporte de mercancías en la costa gallega y cuyo uso para el transporte de sal hasta Betanzos también hemos documentado ${ }^{42}$. Pero a pesar de todo seguía siendo un puerto incómodo requiriendo no en pocas ocasiones la asistencia de pilotos o prácticos del lugar (a cuenta del alfolí) $)^{43}$, que pudiesen atracar las carabelas cargadas de sal sin inconveniente alguno y sin sufrir percances, como el anteriormente referido, que dejasen temporalmente desabastecido el alfolí.

Además de tener que soportar los abusos de los receptores del alfolí, que, como el de Betanzos, se aprovechaban del sistema de medición para

${ }^{41}$ Entre el 7-2-1603 y el 2-12-1604 entraron en el puerto de Coruña con sal las carabelas portuguesas nombradas «Cuerpo Santo» de Antonio Andrés, vecino de Vila do Conde, que dejó 862 fanegas y media, «Santo Antonio» de Bastián González, vecino de Azurara, que descargó 710 medidas, además de un navío sin especificar también portugués denominado «San Salvador» de Antonio Jorge Blanco de la localidad de Matosinhos con 1.348 fanegas y la urca "La Esperanza» del francés Nicolás Dupis con 2.465 fanegas, además de otras tantas carabelas presumiblemente portuguesas en su mayoría: «San Francisco», «San Roque», «Nuestra Señora del Buen Viaje», «San Juan Bautista» y «Nuestra Señora de la Ayuda». Con anterioridad a todas ellas desde el 2 de noviembre de 1602 dejaron sal en Coruña los siguientes barcos sin que nada sepamos de ellos más que el nombre: «Santa Catalina», «La María», «La Madalena» (dos veces), «La Micaela», «Librel» (sic), «La Juliana» (dos veces), «La Salamandria» (sic), «La Uliba» (sic), «La Bendición de Diós», «La Luysa» (sic), «La Juana», «La Leona», «San Juan» y «Santo Antonio». A.R.G., Fondo Real Audiencia, leg. 8.276, $\mathrm{n}^{\circ} 12$.

${ }^{42}$ En cuanto a las características de estas embarcaciones desaparecidas desde principios del siglo XX, sabemos que eran semejantes a las "xeiteiras» aunque de un tamaño mayor y provistas de dos palos con velas de relinga, además de estar tripuladas por diez o doce hombres. ROMANÍ GARCÍA, A: La pesca de bajura ..., pp. 24-25.

${ }^{43}$ «....Mas seis reales que pagó a un piloto por meter una caravela de sal...», Apéndice documental II, fol. $78 \mathrm{r}$.

«CUADERNOS DE ESTUDIOS GALLEGOS», Tomo L, Fascículo 116, Santiago 2003. 
obtener una mayor ganancia en detrimento de los vecinos, no menos problemática fue la relación del concejo con los administradores de los alfolíes de Galicia como A. Fernández Delgado y su sucesor en el cargo Juan Martínez Aragonés. Éstos trataron de privar al concejo de Betanzos del cobro del portazgo de la sal que salía de la ciudad, siendo necesaria la intervención de la Real Audiencia de Galicia en el año 1578 para defender los intereses del concejo ${ }^{44}$. Vemos pues que, tanto en Betanzos como en Coruña, durante este periodo fueron muy tensas las relaciones de ambos concejos con unos receptores y administradores en la mayoría de los casos corruptos o más preocupados por su enriquecimiento y ascenso personal que por el cumplimiento de su cometido. Llegando este conflicto a casos extremos como el encarcelamiento del receptor del alfolí coruñés durante la crisis de 1574-75, habiéndose documentado a lo largo del presente artículo sucesivos enfrentamientos en los años de 1576, 1578, 1582, 1598-99 y a principios del siglo XVII desde el año 1603 en adelante.

\section{Barcos, maestres y rutas de la sal en 1565 y 1570}

\section{(A Coruña y Betanzos)}

\begin{tabular}{llll}
\hline Fecha & Tipo de barco y nombre & Maestre & Ruta \\
\hline $\mathbf{1 5 6 5}$ & Nao «La Trinidad» & Gaspar Díaz (Aveiro, Portugal) & Aveiro - Coruña \\
$\mathbf{1 8 - 5}-6 \mathbf{5}$ & Navío «Nra. Sra. de la Humildad» & Pedro de Abilles (Coruña) & Lisboa - Coruña \\
$\mathbf{2 5 - 5 - 6 5}$ & Carabela «Santo Espíritu» & Fernán Rodríguez (Tavira, Portugal) & Sanlúcar - Coruña \\
$\mathbf{1 5 - 6 - 6 5}$ & Nao «La Concepción» & Pedro Álvarez (Leza, Portugal) & Puerto S. María - Cor. \\
$\mathbf{1 - 8 - 6 5}$ & Navío «Nra. Sra. de la Humildad» & Pedro de Abilles (Coruña) & Lisboa - Coruña \\
$\mathbf{1 7 - 8}-6 \mathbf{5}$ & Una pinaza & Juan de Segura (País Vasco) & País Vasco - Coruña \\
$\mathbf{3 1 - 8 - 6 5}$ & Navío «El Cuerpo Santo» & Juan González (Leza, Portugal) & Aveiro - Coruña \\
$\mathbf{6 - 9 - 6 5}$ & Carabela «La Victoria» & Manuel Afonso (S. Juan de Foz, Por.) & Sanlúcar - Coruña \\
$\mathbf{1 5 7 0}$ & Carabela «Santa Cruz» & Manuel Gómez (Aveiro, Portugal) & ¿Aveiro? - Betanzos \\
$\mathbf{1 3 - 1 1 - 7 0}$ & Carabela «Espíritu Santo» & Bastián González (Esposende, Por.) & ¿? - Betanzos \\
$\mathbf{2 3 - 1 1 - 7 0}$ & Carabela «Santo Antonio» & Bastián González (Aveiro, Portugal) & ¿Aveiro? - Betanzos \\
$\mathbf{2 3 - 1 1 - 7 0}$ & Carabela «San Marcos» & Roque Luís (Aveiro, Portugal) & ¿Aveiro? - Betanzos \\
$\mathbf{1 5 7 0}$ & Carabela «Santo Antonio» & Salvador Pérez & ¿? - Coruña* \\
$\mathbf{1 5 7 0}$ & * Dos volanteros & ¿? & Coruña - Betanzos \\
\hline
\end{tabular}

${ }^{44}$ En 1578 los vecinos se querellan contra Juan Martínez Aragonés en razón de ello: «...y puede aber tres años poco más o menos que A. Fernández Delgado, defunto, su antecesor administrador que fue de los alfolies deste reyno mandó que en la çibdad de Betanzos no se llebe ni cobre çiertos derechos de portazgo que en la dicha çibdad se cobra de la sal que sale del alfoli de la dicha çibdad...», A.R.G., Fondo Real Audiencia, leg. $15.635, \mathrm{n}^{\circ} 80$.

«CUADERNOS DE ESTUDIOS GALLEGOS», Tomo L, Fascículo 116, Santiago 2003. 


\section{APÉNDICE CRONOLÓGICO}

1564 Felipe II amplía el monopolio de 1338 incorporando al poder real todas las salinas de Castilla excepto las de Andalucía y Granada.

1565 Antonio González de Candame es, al menos desde ese año, receptor del alfolí de Coruña hasta 1569 .

1566 Visita de un enviado del rey a los alfolíes gallegos incluyendo los de Betanzos y Coruña.

1570 Cristóbal Román es receptor de Coruña y Andrés de Nebreda receptor del alfolí de Betanzos.

Naufragio de una carabela portuguesa cargada de sal en Betanzos.

1571 El «juro de la sal» del monasterio de Sobrado (40 moyos) se convierte en $40.000 \mathrm{mrs}$.

1574 Crisis de la sal y provisión real aconsejando sobre la necesidad de dar prioridad en la estiba a los barcos de la sal que recalasen en los diferentes puertos. El concejo coruñés interviene unas partidas de sal a unos mercaderes foráneos.

1575 Continúa la carestía y el teniente de la ciudad de Coruña encarcela al receptor del alfolí Pedro de Lago por vender sal a los extranjeros en detrimento de los vecinos.

1576 El concejo de Coruña pretende hacerse con el control del alfolí de dicha ciudad.

1578 El concejo de Betanzos se querella contra el administrador de la sal Martínez Aragonés por impedirles cobrar el portazgo de la sal.

1582 Coruña y Pontevedra acuerdan hacer frente común para hacerse con el control de sus respectivos alfolíes.

1584 Andrés de Nebreda es ahora receptor del alfolí de Coruña y entrega 40.000 mrs. al monasterio de Sobrado por el «juro de la sal» y otros $15.250 \mathrm{mrs}$. a la cofradía de mareantes de San Andrés.

1585 Andrés de Nebreda continúa en su cargo y entrega medio año de renta $(15.500 \mathrm{mrs}$.) a la cofradía de San Andrés, al igual que al monasterio de Sobrado (20.000 mrs.), aunque en este caso a través del prior del monasterio de Nuestra Señora de las Cascas (Betanzos).

1586 El receptor Andrés de Nebreda entrega 30.500 mrs. a los vicarios y mayordomos de la cofradía de mareantes de San Andrés.

1598 Nueva crisis de la sal. Provisión real sobre el precio abusivo de la sal. Se producen epidemias y hambrunas en Coruña y Betanzos que coinciden con la escasez de sal.

1599 Persiste la crisis y el procurador de Coruña, Luís do Campo, se dirige a la Real Audiencia de Galicia sobre la escasez y elevado precio de dicho producto para que informe al rey.

1603 El administrador de la sal en Galicia, Antonio Pereira, y el receptor del alfolí de Coruña, Rodrigo Álvarez, no pagan al hospital de Santa Lucía de la orden de San Lázaro la renta de la sal que éstos percibían desde los tiempos de los reyes católicos.

«CUADERNOS DE ESTUDIOS GALLEGOS», Tomo L, Fascículo 116, Santiago 2003. 


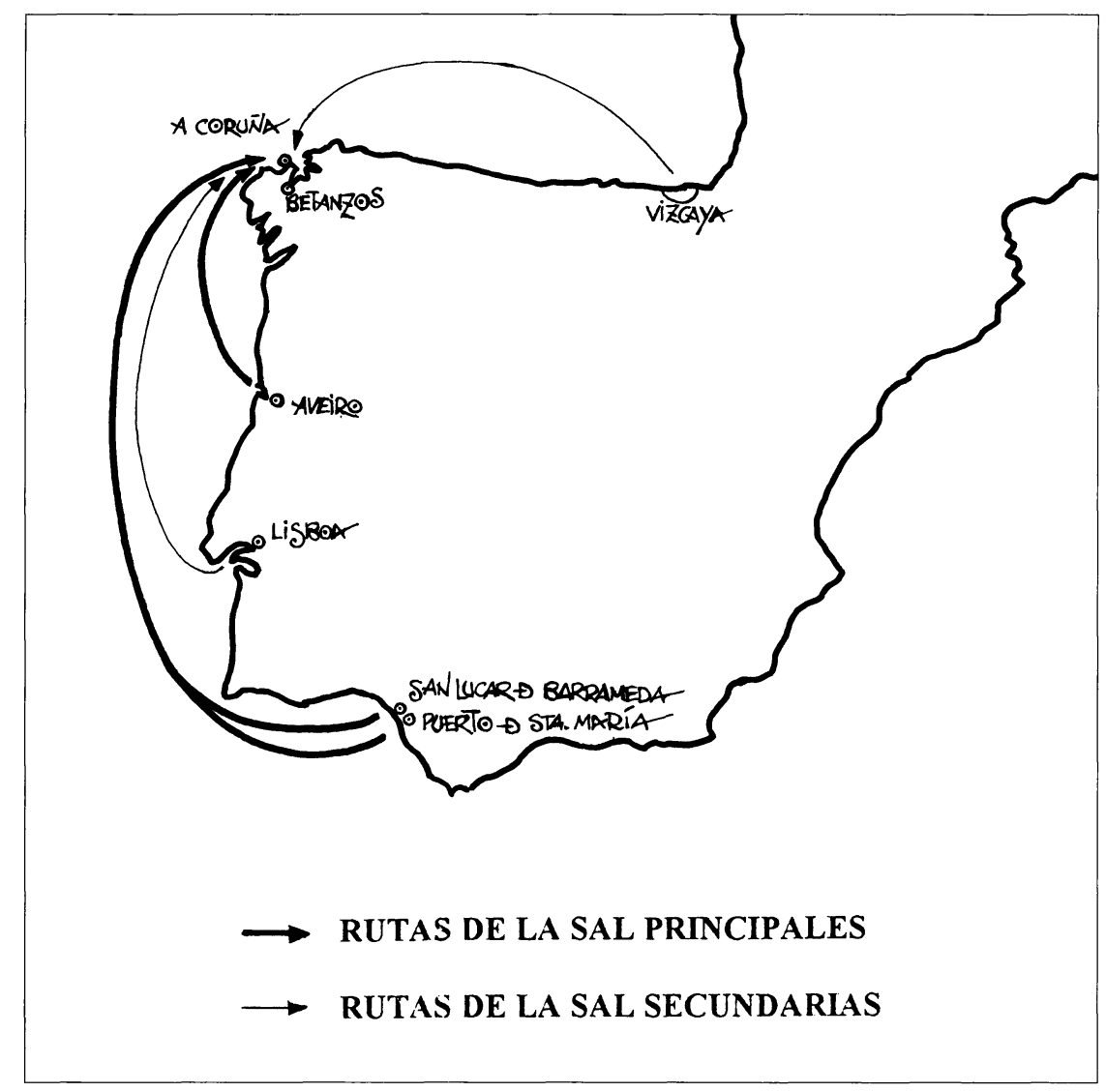

«CUADERNOS DE ESTUDIOS GALLEGOS», Tomo L, Fascículo 116, Santiago 2003. 


\section{APÉNDICE DOCUMENTAL}

Libros de cuentas de los alfolíes de A Coruña y Betanzos

\section{I}

1566, enero, 1. A Coruña.

Copia del libro de cuentas del alfolí de Coruña correspondiente al año 1565, presentado ante el administrador general de la sal y alfolíes del reino de Galicia.

A.M.C., Protocolos notariales s. XVI, $\mathrm{n}^{\circ} 2$.

${ }^{422 r}$ En la çiudad de La Coruña a primero día del mes de henero año del señor de mill y quinientos y sesenta y seis años. Ante el muy magnifico señor Christóbal de Barros, administrador de la sal y alfolíes deste reino de Galizia por su magestad y en presençia de my, Alvaro Alonsso Ballo, scrivano de su magestad y uno de los del número de la dicha çiudad por su magestad real y scrivano ansi mesmo nonbrado para la descarga de la sal del alfolí a su magestad pertenesçiente en la dicha çiudad. Luego su merced hizo paresçer delante sí a Antonio Gonçález de Candame, reçetor del dicho alfolí de la dicha ciudad por su magestad y a mí el dicho scrivano y paresçidos nos mando exibir y presentar los libros de las descargas de la sal que se han hecho para el dicho alfolí originalmente y de los demas cargos que por razón del dicho officio se an hecho al dicho reçetor. $\mathrm{E}$ visto por su merçed y los descargos quel dicho Antonio Gonçález da, hizo con el un tanteo de quenta dende veinte e siete días del mes de abrill del año pasado de mill e quinientos e sesenta y cinco años en que fue nonbrado por tal receptor en el dicho officio hasta postrero de dezembre del dicho año, para abisar a su magestad de la sal y dineros que ay en poder del dicho receptor el qual se hizo en la forma y manera que se sigue.

Margen izquierdo: Cargo de dinero.

Margen derecho: $\mathrm{LXVIII}^{\circ}$ mill.

Hazese cargo al dicho receptor de dos mill reales que balen sesenta y ocho mill maravedís, que resçibió el dicho Antonio González de Candame 
por librança del dicho señor administrador de Diego Muñoz, vezino de Ogarrio, para que mejor pudiese prober de sal el dicho alfoly.

${ }^{422 v}$ Mas se le haze cargo de tres mill reales que resçivió del dicho Diego Muñoz, por mano de Rodrigo de Miranes, por horden del dicho señor administrador y para el dicho hefecto que balen çiento y dos mill maravedís.

Mas se le haze cargo de treinta y quatro mill y nueve çientos y treze reales, que balen un quento y çiento y ochenta y siete mill y quarenta y dos maravedís, por dos mill e doçientas e cinquenta y una medida y un tercio de sal blanca, que bendió contandole por cada una quinze reales que sale cada una de las de Abila por çinco reales y por çiento e veinte e siete medidas de sal de resalga, que bendió a preçio de nueve reales cada medida que sale cada anega de Avila por tres reales. La qual venta constó por su juramento y por su libro donde asienta la sal que bende y por la cantidad de sal que quedaba en su poder.

Por manera que suma el cargo de dinero que se haze al dicho reçeptor un quento y treçientas e çinquenta y siete mill y quarenta y dos maravedís, como consta por las tres partidas arriba contenidas de su cargo.

Margen izquierdo: Descargo de dinero.

Descargase al dicho reçeptor del dicho cargo doze mill e quinientos y noventa y siete maravedís que pago por setenta y ocho medidas de sal blanco, que conpró del nabio nonbrado ${ }^{/ 423 r}$ Nuestra Señora de la Umildad de que hera maestro Pedro de Abilles, vezino de La Coruña, que costo cada medida a precio de cinco reales menos quartillo, que se acabo de descargar a los diez e ocho e diez e nuebe días al mes de mayo del año de sesenta e çinco y la dicha sal hera de la çiudad de Lisbona (sic), reino de Portugal.

Descarganse mas al dicho reçetor sesenta y quatro mill e quatro çientos y treinta maravedís que pago por treçientas y setenta e nueve medidas de sal blanco, que conpró de la carabela Sancto Espirito de que era maestro Fernán Rodrígues, portugués vezino de Tabila, que costó cada medida a precio de cinco reales cada una y hera de Sanlúcar de Barrameda en el

«CUADERNOS DE ESTUDIOS GALLEGOS», Tomo L, Fascículo 116, Santiago 2003. 
reino de la Andaluzía y se acabó de descargar a veinte e cinco dias del mes de mayo del dicho año de sesenta e çinco.

Margen izquierdo: Resalga.

Mas se le descargan siete mill e doçientos e ocho maravedís que pago por çiento y seis medidas de sal de sal (sic) de resalga, que conpró al dicho Fernán Rodrígues, portugués, que costó cada medida dos reales y se acabó de descargar a los veinte seys días del dicho mes de mayo y del dicho año de sesenta e cinco.

${ }^{423 v}$ Yten se le descargan ciento y doze mill e quatrocientos e cinquenta e cinco maravedís que pagó por sietecientas e quarenta medidas de sal blanco, que conpró para el dicho alfolí de la nao portuguesa nonbrada La Concepción de que hera maestre Pedro Álbarez, vezino de Leza, a precio de quatro reales y medio cada una y hera del Puerto de Sancta María en el reino de la Andaluzía y se acabó de descargar a los quinze del mes de junio del dicho año de sesenta y cinco y destas medidas no se le descargan çinco por que no las pago al portugués.

Mas se le descargan treinta y siete mill e quatrocientos maravedís que dio y pagó por librança del dicho señor adminystrador a Pedro Domínguez, vezino de la dicha ciudad de La Coruña, a buen (sic) quenta de lo que su magestad le mandase pagar por por (sic) las doçientas e veinte e seys medidas de sal blanco que se le tomó nesta dicha ciudad.

Descargansele mas cinquenta mill e quinientos e veinte e quatro maravedís que dio y pago por librança del dicho señor administrador a Juan Álbarez de Albreu, vezino del Puerto de Sancta María, a buena quenta de lo que su magestad le mandase pagar por las docientas e sesenta y ocho medidas de sal blanco que se le tomo en esta dicha ciudad.

Mas se le descargan mill e quatrocientos veinte e ocho maravedís que pagó por veinte e una medidas de sal de resalga, que conpró del nabío nonbrado Nuestra Señora de la Humildad de que era maestre Pedro de Abilles, vezino de la dicha ciudad de La Coruña, a precio de dos reales cada una y hera la dicha sal de la ciudad de Lisbona (sic) en el reino de Portogal (sic) y se acabó de descargar a primero de agosto del dicho año de sesenta e cinco.

«CUADERNOS DE ESTUDIOS GALLEGOS», Tomo L, Fascículo 116, Santiago 2003. 
Mas se le descargan del dicho cargo mill e docientos e quarenta y seis maravedís y medio y un cornado, que dio y pagó por siete medidas y un tercio de medida de sal blanco que conpró $/ 424 \mathrm{r}$ para el dicho alfolí de la pinaça vizcaína de que era maestro Juan de Segun (sic), a precio de cinco reales cada medida la qual traya de Vizcaia que alla la avía conprado y se acabó de descargar a diez e siete del mes de agosto del dicho año de sesenta y cinco.

Mas se le descargan veinte e seis mill y ochocientos y setenta y siete maravedís que pagó por ciento e ochenta y seis medidas de sal blanco, que conpró del nabío portugués nonbrado El Cuerpo Sancto de que hera maestro Juan González, vezino de Leza, a precio de quatro reales y quartillo cada una y hera del puerto de Abeiro en el reino de Portogal (sic) y se acabó de descargar a treinta e un días del mes de agosto del dicho año de sesenta y cinco años.

Yten se le descargan ciento y un mill y docientos y sesenta maravedís y medio que pago por seiscientas y veinte y siete medidas de sal blanco, que conpró de la carabela portuguessa nonbrada La Bytoria de que hera maestro Manuel Alonso (sic), vezino del puerto de San Juan da Foz, a precio de quatro reales y tres quartillos cada una y hera la dicha sal del puerto de Sanlúcar de Barrameda en el reino de la Andaluzía y se acabó de descargar a seis días del mes de septiembre del dicho año de sesenta y cinco.

Mas se le descargan noventa y ocho mill e ciento e quinze maravedís y medio que pagó por seisçientas $/^{424 \mathrm{v}}$ y setenta y nueve medidas de sal blanco, que conpró de la nao portoguesa nonbrada La Trinidad de que hera maestre Gaspar Díaz, vezino de Abeiro, a precio de quatro reales y quartillo cada uno y hera del puerto de Abeiro en el reino de Portogal y se acabo de descargar a los siete días del mes de dezienbre del dicho año de sesenta y $\operatorname{cinco}^{45}$.

${ }^{45}$ La fecha correcta es el día 29 de noviembre, ya que la del mes de diciembre se corresponde en realidad con el siguiente descargo de dinero que no aparece consignado aquí. Posiblemente se trate de un error del escribano que realizó el traslado por la similitud de nombres entre Gaspar Díaz y Nicolás Gaspar, que después del portugués vendió más de 42 medidas de sal en el alfolí (véase fol. $428 \mathrm{r}$-v).

«CUADERNOS DE ESTUDIOS GALLEGOS», Tomo L, Fascículo 116, Santiago 2003. 
Mas se le descargan tres mill e seisçientos y ochenta y un maravedís que paresçe aber dado y pagado a Juan de Linares, medidor del dicho alfolí, por aber medido dos mill e seisçientas y ochenta y una medidas de sal.

Mas se le descargan del dicho cargo sietecientos e veinte y dos maravedís que pagó a Bastián do Barral, medidor que ahora hes del dicho alfolí, por sietecientas e veinte y dos medidas que medio de sal.

Yten se le descargan mas diez y seis mill e quinientos reales de plata que balen quinientas e sesenta y un mill maravedís, que pagó por librança del dicho señor administrador a Diego Muñoz, vezino de Ogarrio, para que acudiese con ellos por su horden y librança a la persona que hordenase para fabricar los nabyos.

Mas se le descargan sieteçientas y quarenta y ocho maravedís que por librança del dicho señor adminystrador pagó a Jorje Promontoiro y a Pedro Domínguez, ${ }^{/ 425 r}$ vezinos de la dicha çiudad porque fueron a la ciudad de Sanctiago a dezir sus dichos y depusiciones en çierta caussa que tocó al servicio de su magestad en esta administración.

Mas se le descargan siete mill e quatroçientos y ochenta maravedís que por librança del dicho señor administrador pagó a Alvaro Alonsso Ballo, scrivano del dicho alfolí desta dicha çiudad a buena quenta del salaryo que a de aver de tal scrivano.

Mas se le descargan del dicho cargo çinco mill e trecientos y noventa y un maravedís que pagó por razon de mill e sietecientas y noventa y siete medidas de sal que descargó y los dichos maravedís se le dan por razón de la descarga dando por cada una medida tres maravedís conforme a la primera horden que en esto ubo.

Mas se le descargan dos mill y nuevecientos maravedís que pago a los que descargaron mill y quatroçientas e cinquenta medidas de sal, dando por cada una dos maravedís conforme a una provisyón mía en que generalmente se mandó no se diese más y no se le paga la descarga de ciento y treze medidas por que se bendieron a borde de la nao. 
Mas se le descargan del dicho cargo ochenta y cinco maravedís que dio a unas mugeres que traxeron las medidas porque se bendiese la sal en esta çiudad dende Vetanços donde se fizieron.

${ }^{425 v}$ Mas se descargan ciento y treinta y seis maravedís que pagó a un honbre que fue a Vetanços a hazer marcar las medidas por donde se mide la sal en lo qual se tubo quatro días.

Mas se le descargan ciento y noventa maravedís que pagó a Juan de Pariz, çerrajero por la herraje de las medidas de sal y de una rapa con que se mide en los nabyos.

Mas se le descargan sesenta y ocho maravedís que pagó por otra rapa dara (sic; para) medir la dicha sal.

Mas se le descargan ocho mill e çinquenta y ocho maravedís que pagó por ochenta sacos de olona (sic) que se le mandaron comprar por mi horden para la descarga de la sal.

Mas se le descargan treçientos maravedís que pagó a un peón de a pie por yr y benir a la çiudad de Santiago con lo que se detubo para traer dineros para conprar sal.

Mas se le descargan doçientos y quatro maravedís que pagó a Alonso Martínez, tonelero por hazer una medida grande para medir sal.

Mas se le descargan seisçientos y ochenta maravedís que pagó a Pedro Barela, herrero por herrar la dicha medida grande que está ahora por $\mathrm{Pa}-$ drón en poder del conferidor de la ciudad.

${ }^{426 r}$ Yten se le descargan ciento y treinta y seis maravedís que pago a maestre Luís, marcador de la çiudad por aber conferido las medidas que se conferieron segunda vez.

Descargansele mas quatroçientos y treinta y dos maravedís que pagó a los pobres lazerados desta ciudad, que se les devía por razón de ocho anegas de sal que se les manda dar en dinero a como costó a su magestad y hesto

«CUADERNOS DE ESTUDIOS GALLEGOS», Tomo L, Fascículo 116, Santiago 2003. 
hes del nabío nonbrado Nuestra Señora de la Humilldad de que hera maestro Pedro de Abilles.

Mas se le descargan quatroçientos y cinquenta y dos maravedís que pagó a los dichos Lazerados por las ocho anegas que ubieron de aver del nabyo nonbrado Santo Espiritus de que hera maestro el dicho Fernán Rodrígues.

Mas se le descargan quatrocientos y diez maravedís que pagó ansi mesmo a los dichos Lazerados por las ocho anegas que ubieron de aver del nabío nonbrado La Conçepción de que hera maestre Pedro Álbarez.

Descargansele mas quatrocientos y sesenta y quatro maravedís que pagó ansi mesmo a los dichos Lazerados por las ocho anegas que ubieron de aver del nabío nonbrado El Cuerpo Sancto de que hera maestro el dicho Juan Gonçález.

Mas se le descargan quatrocientos y treinta y dos maravedís que ansi mesmo pagó a los dichos Lazerados por las ocho anegas que se ubieron de aver del nabyo nonbrado La Bictoria de que hera maestro el dicho Manuel Alonso (sic).

${ }^{426 v}$ Mas se le descargan trecientos y sesenta y quatro maravedís que pagó ansi mesmo a los dichos Lazerados de las ocho anegas que ubieron de aver del nabío nonbrado La Trinidad de que hera maestre Gaspar Díaz.

Mas se le descargan quinentos e veinte e siete maravedís que pagó a Felipe Borgonon porque herro cinco medidas questan confiriéndose en poder de maestre Luís con que se a de medir la sal.

Mas se le descargan treze mill e nuevecientos e veynte y tres maravedís, los ocho mill e docientos y veynte y ocho maravedís que dio al mayordomo del cavildo de la colegial de la dicha ciudad, en derechos a buena quenta de lo que an de aber por el alquiler de la lonja donde esta la sal por el año de sesenta e cinco y sesenta y seis, y los cinco mill e seisçientos y noventa y cinco maravedís que a la dicha buena cuenta gasto en adobar la dicha lonja que se les a de descontar del sueldo que se les señalare.

«CUADERNOS DE ESTUDIOS GALLEGOS», Tomo L, Fascículo 116, Santiago 2003. 
Mas se le descargan dos mill y seiscientos y diez e ocho maravedís que por librança del dicho señor administrador pago a Dominga de Monelos por cinco meses que se le tubo ocupado la lonja de su cassa con sal.

${ }^{427 r}$ Por manera que suma el descargo de dinero que da el dicho receptor un $\mathrm{q}^{\mathbf{0}}$ y ciento y veinte y seis mill y trecientos y treinta y siete maravedís y medio y un cornado, como consta por las treinta y siete partidas arriba contenidas de su descargo, que sacados del un quento y treçientos y çinquenta mill y quarenta y dos maravedís que se le hizieron de cargo de dinero, resta debiendo docientas y treinta mill y sieteçientos y quatro maravedís y dos cornados de los quales se le haze cargo para el año de sesenta y seis.

\section{Cargo de sal}

Hazesele cargo al dicho Antonio Gonçález, receptor susodicho, de setenta y ocho medidas de sal blanco que conpró al dicho Pedro de Abilles, vezino de La Coruña, maestre de su nabío, a precio de çinco reales menos quartillo cada una que se acabó de descargar a diez e ocho y diez e nueve días del mes de mayo del año de mill e quinientos y sesenta y çinco.

Mas se le cargan treçientas y setenta y nuebe medidas de sal que conpró para el dicho alfolí a Fernán Rodrígues, portogués vezino de Tabila, maestre de su carabela a precio de cinco reales cada una y se acabó de descargar a veinte e cinco de mayo del dicho año de sesenta y çinco.

Margen izquierdo: Resalga.

Mas se le haze cargo de ciento y seis medidas de sal de resalga que conpró al dicho Fernán /27v $^{420 d r i ́ g u e z, ~ a ~ p r e c i o ~ d e ~ d o s ~ r e a l e s ~ c a d a ~ u n a ~ y ~ s e ~ a c a b o ́ ~}$ de descargar a veinte y seis días del dicho mes de mayo y del dicho año de sesenta y çinco.

Mas se le cargan sietecientas y quarenta medidas de sal blanco que conpró para el dicho alfolí a Pedro Albarez, vezino de Leza, maestre de su nabío, a precio de quatro reales y medyo cada una, la qual se acabó de descargar a quinze días del mes de junio del dicho año de sesenta y çinco.

«CUADERNOS DE ESTUDIOS GALLEGOS», Tomo L, Fascículo 116, Santiago 2003. 
Mas se le haze cargo de doçientas e veinte y seis medidas de sal blanco que rescivió para el dicho alfolí, las quales se tomaron a Pedro Domínguez, mercader vezino de la dicha ciudad, quando se tomó el dicho alfolí por su magestad y se acabaron de medir a los cinco días del mes de jullio del dicho año de sesenta y cinco.

Yten se le cargan mas docientas y sesenta y ocho medidas de sal blanco que resçivió ansi mesmo para el dicho alfolí y se tomaron a Juan Álbarez de Albreu, vezino del puerto de Sancta María, al tiempo que se tomó el dicho alfolí por su magestad las quales se acabaron de medir a los nueve del mes de jullio del dicho año de sesenta y çinco.

Margen izquierdo: Resalga.

Mas se le cargan veinte y una medidas de sal de resalga que conpró para el dicho alfolí al dicho Pedro de Abilles, vezino de la dicha çiudad, $/{ }^{428 r}$ a precio de dos reales cada una y se acabaron de descargar a primero día del mes de agosto del dicho año de sesenta y cinco.

Mas se le cargan siete medidas y un tercio de medida de sal blanca que conpró a Juan de Segura, vizcaíno maestre de su pinaça, a precio de çinco reales cada una y se descargó a diez e siete días del dicho mes de agosto y del dicho año de sesenta e çinco.

Mas se le cargan ciento e ochenta y seis medidas de sal blanco que conpró a Juan González, portogués vezino de Leza, maestre de su nabyo, a precio de quatro reales $\mathrm{y} \mathrm{q}^{\circ}$ cada una y se acabaron de descargar al postrero del dicho mes de agosto del dicho año de sesenta e çinco.

Mas se le cargan seisçientas e veinte y siete medidas de sal blanco que conpró para el dicho alfolí a Manuel Afonso, vezino de San Juan de Foz, a precio de quatro reales y tres quartillos cada una y se acabaron de descargar a seis días del mes de setenbre del dicho año de sesenta e çinco.

Mas se le cargan seisçientas y setenta y nuebe medidas de sal blanco que conpró a Gaspar Díaz, portogués vezino de Abeiro, maestre de su nao, a precio de quatro reales $\mathrm{y}^{\mathbf{0}}$ cada una y se acabó de descargar a veinte $\mathrm{e}$ nueve días del mes de noviembre del dicho año de sesenta e çinco. 
${ }^{428 v}$ Mas se le cargan quarenta y dos medidas y dos terçios de medida y media fanega de Abila de sal blanco, que resçivió para el dicho alfolí y se tomó a Nicolao Xaspar, mercader vezino de la dicha çiudad al tienpo que por su megestad se tomó el dicho alfolí y se acabo de medir a seis días del mes de dezenbre del dicho año de sesenta e çinco años.

Por manera que monta el cargo de sal que se haze al dicho receptor tres mill e docientas y treinta y tres medidas de sal blanca de las grandes al pisar por donde se descargan y miden los nabíos y media fanega por la de Abila que hes un sesmo de media y mas çiento e veinte e siete medidas de sal de resalga como consta por las doze partidas arriba contenidas de su cargo.

\section{Descargo de sal}

Descarganse al dicho recetor del dicho cargo dos mill e doçientas e cinquenta y una medidas y un tercio de sal blanco que declaró aber bendido y del dinero dellas se le ha hecho cargo en el cargo del dynero y ansi mesmo se le descargan ciento e veinte e siete medidas de sal de resalga, porque se le hizo cargo dellas en el cargo del dinero por aberlas bendido que sacadas las dos mill e docientas e cinquenta e una e un tercio $/ 429 \mathrm{r}$ de las tres mill y docientas y treinta y tres y un sesto de sal blanco de que se le hizo cargo. Quedan en poder del dicho receptor nueveçientas y ochenta y dos medidas menos un sesto de las grandes de sal blanco que son por la anega de Avila dos mill y nuevecientos y quarenta y cinco fanegas y media y abiendo bendido y descargándosele ciento e veinte e siete medidas de sal de resalga y sacándolas de otras tantas que se le hizieron de cargo no queda en su poder sal de resalga alguna.

E después de lo susodicho estando en la villa de Ferrol, a veinte e ocho días del mes de agosto del año del señor de mill e quinientos y sesenta y seis años, estando antel muy magnifico Christóbal de Barros, administrador susodicho y estando presente el dicho Antonio Gonçález de Candame, receptor del alfoly a su magestad pertenesçiente en la dicha çiudad de $\mathrm{La}$ Coruña y en presencia de my el dicho scrivano, luego su merced tomó y rescivió juramento del dicho receptor y de mí el dicho scrivano en forma de vida e de derecho a Dios e a Santa María e a las palabras de los sanctos

«CUADERNOS DE ESTUDIOS GALLEGOS», Tomo L, Fascículo 116, Santiago 2003. 
hebangelios a donde quiera que mas largamente estan scrytos y sobre una señal de cruz en que pusymos nuestras manos derechas corporalmente que dixesemos y declarasemos la verdad de lo que supiesemos y porque fuesemos preguntados e que si la verdad dixesemos que Dios nuestro señor nos ayudase en este mundo a los cuerpos y en el otro a las animas donde mas abemos de $/{ }^{429 v}$ durar y si la verdad no dixesemos que a nos nuestro señor nos lo demandase mal y caramente como a malo christianos, que sabiendo la verdad juraban su sancto nonbre en bano y nos los dichos receptor y scrivano ausolbiendo la fuerça y confisión del dicho juramento cada uno de nos por sí dixo sí juro e amen e prometimos de dezir verdad de lo que supiesemos y porque fuesemos preguntados, so cargo del qual dicho juramento el dicho señor administrador nos mandó que digamos y declaremos sy nos o otro por nos o cada un de nos o otra persona alguna sepamos que aia fecho a su magestad fraude o engaño en el dicho alfolí y descargo de sal o en lo a él anexo o si sabemos de otra persona alguna que lo aia fecho y si en las dichas quentas de atrás a abido fraude o engaño a su magestad o si se a bendido mas sal del que se a dado por quenta y esta declarado. A lo qual respondymos que no abíamos fecho fraude a la hazienda de su magestad, antes hemos fecho lo que somos obligados ni sabemos de otra persona alguna que lo aia fecho y que en las dichas quentas según dicho hes no a abido fraude ny engaño contra su magestad ni su real hazienda, antes son buenas y verdaderas que poco más o menos el dicho recetor dixo no a bendido mas sal de lo que esta declarado y se le a fecho cargo de dinero. Y luego nos fue dicho y encargado e mandado por el dicho señor admynistrador, que si ahora o en algún tiempo a nuestra noticia biniese socargo del dicho juramento hecho que ubiese algún fraude o engaño en las dichas quentas o en otra cosa contra el dicho alfolí de la dicha ciudad de su magestad o otra alguna persona lo ubiese hecho lo declarasemos y manifestasemos al dicho administrador estando a ello presentes por testigo Juan de la Maza, scrivano y Francisco Maldonado y otros Christóbal de Barros, Antonio Gonçález de Candame. Paso ante mí Alvaro Alonsso Ballo, scrivano.

${ }^{430 r}$ E luego en continiente el dicho señor adminystrador hizo pregunta al dicho Antonio Gonçalez de Candame, receptor susodicho y le dixo que bien save que al tiempo que le encargo el dicho officio en un capitulo de la ystrución que le dyo se contiene y hordena que tenga quenta en el 
entretanto que se be lo que a de aber por las mermas si las ubyere y tenga quenta con ver si sobra alguna sal al tiempo que lo [...] de [...]de lo que a rescivido y que por questo que [...] de ser por su magestad pues a acabado de bender la sal que estaba en la lonja de peligro y la que estaba en la lonja grande y la que estaba en la lonja de Dominga de Monelos y finalmente toda la sal de que se le a fecho cargo del año de sesenta y cinco, diga y declare so cargo del dicho juramento si le a sobrado alguno para hazerle dello cargo, el qual dixo que hera verdad que el abía bendido toda la dicha sal eçepto cien fanegas de Abila que no las acabo de bender pero que las medyo para saber la merma o sobra que avya y que vista su quenta alló de falta mill e ochocientos y setenta e ocho reales de toda la dicha sal y su [...] mando ansy sentar testigos los dichos Christóbal de Barros, Antonio Gonçález de Candame. Paso ante mí Alvaro Alonso Ballo.

E yo el dicho Alvaro Alonso Ballo, escribano de su magestad en la su corte, reinos e señoríos y uno de los del número de la çiudad de La Coruña, por su magestad real bien y fielmente fiz sacar y trasladar estas quentas del original que queda en mi poder de pedimiento de Antonio Gonçález de Candame y pongo aquí estos mi nombre e signo que es a tal.

En testimonio (signo) de verdad.

Alvaro Alonso Ballo (rubricado).

II

1571, enero, 1. A Coruña.

Copia del libro de cuentas del alfolí de Betanzos correspondiente al año 1570, presentado ante el administrador general de la sal y alfolíes del reino de Galicia.

A.M.C., Protocolos notariales, $n^{\circ}$ 1, Juan López de Taibo, 1570-1571.

${ }^{77 r}$ Relación y quenta fecha en la ciudad de La Coruña a primero día del mes de henero año del señor de mill y quinientos y setenta y un años con Andres de Nebreda, reçetor del alfolí de la ciudad de [tachado: La Coruña] Betanços, desde fin de otubre del año pasado de qinientos y setenta

«CUADERNOS DE ESTUDIOS GALLEGOS», Tomo L, Fascículo 116, Santiago 2003. 
hasta oy día de la fecha, así de la sal que ha reçivido y bendido en el dicho tiempo, la qual le fue tomada por Jacobe de Agurto, administrador general de los naipes deste reyno de Galiçia y principado de Asturias por su magestad e por comysión del señor Pedro Ramos, administrador general de los alfolís deste reyno por su magestad, se hizo la dicha quenta tocante a la dicha sal en la manera seguiente.

\section{Cargo de sal}

Margen izquierdo: Maravedís. L mill CCCC ${ }^{\circ}$ LVI.

Margen derecho: Fanegas. I mill CXIII.

Hazesele cargo al dicho Andrés de Nebreda, reçetor, de trezientas y setenta y una medidas de sal que conpró y resçivió en treze de noviembre de Bastián Gonçález, vezino de Esposende, maestre de su carabela nonbrada Espíritu Sancto, a preçio de quattro reales cada medida y pago por ellos çinquenta mill y quattroçientos y cinquenta y seis maravedís, los quales se le hazen buenos a su quenta de dinero.

Margen izquierdo: III mill CCCC ${ }^{\circ}$

Margen derecho: LXXV.

Mas se le haze cargo de veynte e çinco medidas de sal que conpró e resçivió en veynte e tres de novienbre de Bastián Gonçález, vecino de Abero, maestre de su carabela nonbrada Santo Antonio, a preçio de quattro reales cada medida y pagó por ellas çien reales. Esta caravela llevava tres millares de sal y con gran dullubio ( $\mathrm{sic}$ ) e mareas estando amarrada en la dicha çiudad de Betanzos dio al través en la puente donde se anegó toda la sal, eçeto las dichas veynte e çinco medidas y esto se aberiguó ser asy verdad.

\section{Margen izquierdo: XLIII mill CCC LXXX ${ }^{\circ}$ IIII $^{\circ}$.}

Margen derecho: DCCCC ${ }^{\circ}$ LVII.

Mas se le haze cargo de treszientas e diezenuebe medidas de sal que conpró e resçivió en veynte y tres de novienbre de Roque Luís, vecino de Abero, maestre de su carabela nonbrada San Marcos, a presçio de quattro reales cada medida e pago por ellas quarenta y tres mill e trezientos e ochenta y quattro maravedís. 


\section{Margen izquierdo: XLII mill DCCCC ${ }^{\circ}$ LXX VI.}

Margen derecho: DCCCCXLVIII ${ }^{\circ}$.

Mas se le haze cargo de trezientas e diez e seis medidas de sal que conpró y resçivió de Manuel Gome ( $\mathrm{sic}$ ), vecino de Abero, maestre de su carabela nonbrada Sancta Cruz, a presçio de quattro reales cada medida que pago por ellas quarenta y dos mill nobeçientos y setenta y seis.

\section{Margen izquierdo: V mill CC XXX VI.}

Margen derecho: DLXX.

Mas se le haze cargo de çiento y nobenta medidas de sal que se le ynbiaron desta çiudad de La Coruña en dos bolanteros, que se resçivieron de la carabela nonbrada Santo Antonio de ques maestre Salvador Perez, en que traya dozientos e veynte e çinco moyos. E lo demás que traya la dicha carabela lo resçivió Christóbal Roman, reçetor desta çiudad, e pago de fletes a los dichos bolanteros catorze ducados.

${ }^{77 v}$ Margen derecho: III mill DC LX III.

Por manera que monta el cargo de sal que así se haze a dicho reçetor como pareçe por las partidas arriva declaradas tres mill y seisçientas y sesenta y tres fanegas de sal.

\section{Datta de sal}

Margen izquierdo: CCC LXXIII mill DXCII.

Margen derecho: II mill DCCXLVII.

Resçivesele en quenta al dicho reçetor dos mill y seteçientas y cuarenta y siete fanegas de sal que da por bendido en la lonja, que contadas a razón de quatro reales la fanega balen trezientas y setenta y tres mill e quinientos y nobenta i dos maravedís.

\section{Margen izquierdo: CII mill D CCC ${ }^{\circ}$ XVI.}

Margen derecho: DCC LVI.

Mas se le resçiben en quenta seteçientas y çinquenta e seis fanegas de sal que bendió en los navíos de que no se debe merma, que contadas a razón de quattro reales la fanega valen çiento y dos mill e choçientos y diez e seis maravedís, los quales se le cargan a su quenta de dinero.

«CUADERNOS DE ESTUDIOS GALLEGOS», Tomo L, Fascículo 116, Santiago 2003. 
Margen derecho: C LX.

Mas se le rescive en quenta çiento y sesenta fanegas de sal que se le paga e ubo de pagar por la quiebra y merma de dos mill y nobeçientas [tachado: y quarenta] y siete fanegas que bendió de contado que a razón de çinco e medio por çiento monta lo dicho.

Margen izquierdo: $\mathrm{CCCC}^{\circ} \mathrm{LXX}$ VI mill $\mathrm{CCCC}^{\circ} \mathrm{VIII}^{\circ}$. Margen derecho: III mill DC LX III.

Por manera que monta [...] de sal segund pareçió por las partidas arriba declaradas.

Cargo de dinero

Margen derecho: Maravedis. $\mathrm{CCCC}^{\circ}$ LXX VI mill $\mathrm{CCCC}^{\circ} \mathrm{VIII}^{\circ}$.

Hazesele cargo al dicho reçetor de quattro çientas y setenta y seys mill e quatrozientas [tachado: e sesenta] y ocho maravedís por la sal, que bendió así de contado como a bordo como en las dos partidas avajo escritas e se contiene.

Margen derecho: XC III mill D.

Mas se le haze cargo de dozientos e çinquenta ducados que resçivió de Martín de Salas que avía cobrado de Fernando de Lassa porque fue executado.

Margen derecho: C XL IX mill DC.

Mas se le haze cargo de çiento y quarenta e nuebe mill y seisçientos maravedís que quedó deviendo en la quenta pasada que se le tomo en Betanços a çinco días del mes de noviembre como por ella parece.

Margen derecho: DCC XIX mill D VIII'.

Por manera que monta el cargo de dinero que se haze al dicho reçetor como parece seteçientos e diez e nuebe mill e [tachado: quattro] quinientos [tachado: e sesenta] e ocho maravedís.

«CUADERNOS DE ESTUDIOS GALLEGOS», Tomo L, Fascículo 116, Santiago 2003. 
Datta de dinero

Margen derecho: C XLV mill CCCC ${ }^{\circ}$ LII.

Resçivesele en quenta al dicho reçetor çiento e quarenta e çinco mill quattro çientos e çinquenta y dos maravedís que pagó a los maestres de la sal que resçivió como por sus partidas se declara.

${ }^{78 r}$ Margen derecho: $\mathrm{V}$ mill DCCCC ${ }^{\circ}$ LXIX.

Mas çinco mill e nobeçientos e sesenta e nuebe maravedís que pagó al pisador y carretos quitado el carreto de lo que se bendió a bordo y pisador de la sal que se ynbió desta ciudad.

Margen derecho: LXXIII mill XXXII.

Resçivesele en quenta dos mill e çiento y quarenta y ocho reales que pago a Jacove de Agurto a buena quenta en la quenta passada como por ella parece.

Margen derecho: LVI mill C.

Mas se le resçibe en quenta çinquenta e seis mill e çien maravedís que pagó a Pedro Gato, por orden del señor administtrador como parece por su carta de pago que enttrego al dicho señor administtrador.

Margen derecho: XVI mill DCLXVI.

Mas se le resçive en quenta que pago a Pedro de Prol, mayordomo de la çiudad de Betanços, diez e seis mill y seisçientos y sesenta e seis maravedís por el primero e segundo tercero del juro que en cada un año tiene la dicha çiudad sobre el alfolí de que enttregó los recaudos al dicho señor administtrador.

Margen derecho: CXV mill DCCII.

Mas se le resçive en quenta tres mill e seteçientos y nobenta y dos reales que parece aver prestado en quartos a Fernando Darriba, Basco Lope, Gil Barela y Suero de Bezerra, vecinos de Betanços, de que entregó las obligaciones de la dicha quantía al dicho señor administtrador con que se obliga si las dichas obligaciones no salieren çiertas sea a su cargo, eçeto la de Gil Barela que dio por orden del dicho señor administrador y destos maravedís se le baxan trezientos y ochenta e nuebe reales que el dicho

«CUADERNOS DE ESTUDIOS GALLEGOS», Tomo L, Fascículo 116, Santiago 2003. 
Nebreda cobró de çiertas condenaçiones de Ruy de Pazos y Pedro de Rosende, vecinos de Betanços, en que liquidamente quedan çiento y quinze mill y seteçientos y dos maravedís.

Margen derecho: XVI mill CCCC ${ }^{\circ}$ LVI.

Mas quarenta y quattro ducados que pagó a Alonso Conde, herrero, por ferrar treze medidas grandes y ottras de media anega e quartas anegas e chupines e rodos, de que mosttró carta de pago signada e firmada de Luís Méndez, escribano, donde mas largamente se contiene aver hecho la paga.

Margen derecho: CC XXXVIII.

Mas siete reales que pagó a Juan Méndez, conferidor, por conferir çiertas medidas e aderezar la medida grande de que mostró carta de pago.

Margen derecho: CCIIII.

Mas seis reales que pagó a un piloto por meter una caravela de sal que así fue conçertado por Jacove de Agurto.

78v Margen derecho: CXXV mill $\mathrm{CCCC}^{\circ}$.

Mas que pagó al dicho señor administrador oy día de la fecha dicha çiento e veynte e çinco mill e quattro çientos maravedís digo que los recivió los dichos çiento y beinte y çinco myll y quatrocientos maravedís el señor Pedro Ramos.

Margen derecho: DLV mill CCXIX. Alcanze. CLXIIII ${ }^{\circ}$ mill CC LXXX IX .

Por manera que monta la dacta de dinero como en las partidas arriba declaradas pareze quinientas e çinquenta e çinco mill y duzientos e diez e nuebe maravedís, que rebatidos de las seteçientas e diez e nuebe mill e quynientos [...] y ocho maravedís del dicho su cargo que de resto alcançado en conformidad en çiento y sesenta y quattro mill e duzientos e hochenta e nuebe maravedís.

La qual dicha quenta se hizo [...] con el dicho Andrés de Nebreda, reçetor, en la manera susodicha el qual juro en forma de derecho que la ha hecho buena e felmente sin yncubrir cossa alguna e que si lo supiere e biniere asi notificado lo declarara e se obligó en forma de pagar e que pagará el 
dicho alcance llanamente e asy anbas las dichas partes lo firmaron de sus nonbres, siendo presentes por testigos Pedro de Vergara, criado del dicho Jacobe de Agurto e Joan Montero, criado de mi el presente escrivano.

Jacobe de Agurto (rubricado).

Andrés de Nebreda (rubricado).

Son CLXIIII ${ }^{\circ}$ mill CC LXXX' IX maravedís.

Juan Lopez de Taibo (rubricado).

\section{BIBLIOGRAFÍA}

ARMAS CASTRO, José: Pontevedra en los siglos XII a XV, Fundación Pedro Barrié de la Maza, La Coruña, 1992.

CASTIÑEIRA CASTRO, Víctor Manuel: «El litoral gallego y el abastecimiento de sal a mediados del s. XVI», Obradoiro de Historia Moderna, $\mathrm{n}^{\circ}$ 8, Santiago de Compostela, 1999, pp. 7-30.

CORTES de los antiguos reinos de León y Castilla, Real Academia de la Historia, 1883-1903.

FERREIRA PRIEGUE, Elisa: Galicia en el comercio marítimo medieval, Fundación Pedro Barrié de la Maza, La Coruña, 1988.

«O desenvolvemento da actividade pesqueira desde a alta Idade Media ó século XVII», Historia da pesca en Galicia (cord. Carmen Fernández Casanova), Universidad de Santiago de Compostela, Santiago de Compostela, 1998, pp. 51-86.

FREIRE CAMANIEL, José: El monacato gallego en la Alta Edad Media, Fundación Pedro Barrié de la Maza, A Coruña, 1998.

GONZÁLEZ GARCÉS, Miguel: Historia de La Coruña. Edad Media, Caixa Galicia, La Coruña, 1987.

«CUADERNOS DE ESTUDIOS GALLEGOS», Tomo L, Fascículo 116, Santiago 2003. 
MOLINA, Bartolomé Sagrario de: Descripción del reino de Galicia, Colección Bibliófilos Gallegos, Santiago de Compostela, 1949.

ROMANÍ GARCÍA, Arturo: La pesca de bajura en Galicia, Edicións do Castro, A Coruña, 1981.

TETTAMANCY GASTÓN, Francisco: Apuntes para la historia comercial de La Coruña, La Coruña, 1900.

VELO PENSADO, Ismael: La vida municipal de A Coruña en el siglo XVI, Diputación Provincial de A Coruña, A Coruña, 1992. 